\title{
PENYULUHAN PERAN DIGITAL MARKETING DALAM MENINGKATKAN PENJUALAN PRODUK UMKM KERIPIK CIPING DESA SUKAWANA CURUG KOTA SERANG
}

\author{
Reni Febriani \\ Universitas Banten Jaya, J1. Syech Nawawi Albantani Serang Banten, Indonesia \\ Email: renifebriani@unbaja.ac.id
}

\begin{abstract}
This community service basically purpose to provide training and mentoring to "UMKM Keripik Ciping" in Sukawana Village so that they can innovate on the "Keripik Ciping" marketing system which is still traditional and has low mastery of information technology in marketing. Based on these problems, if business actors need knowledge about business management and product commercialization concepts, especially those related to packaging design and marketing using information technology. The method of implementing community service activities is in the form of counseling/socialization on improving packaging design, marketing, training and assisting in the digitalization process of marketing/digital marketing through marketplace/social media. Through this activity, business actors are expected to be able to manage their business for the better and be able to expand market share so that they can support business development and progress which in turn can increase income for "UMKM Keripik Ciping" business actors.
\end{abstract}

Keywords: Packaging; Commercialization; Marketing; Digital Marketing.

\begin{abstract}
ABSTRAK
Pengabdian masyarakat ini pada dasarnya bertujuan untuk memberikan pelatihan dan pembimbingan kepada pelaku UMKM keripik ciping di Kelurahan Sukawana agar dapat berinovasi pada sistem pemasaran keripik ciping yang masih bersifat tradisonal dan rendahnya penguasaan teknologi informasi dalam pemasaran. Berdasarkan permasalahan tersebut, sekiranya pelaku usaha membutuhkan pengetahuan mengenai manajemen usaha dan konsep komersialisasi produk khususnya yang berkaitan dengan desain kemasan dan pemasaran menggunakan teknologi informasi. Metode pelaksanaan kegiatan pengabdian kepada masyarakat yaitu berupa penyuluhan/sosilaisasi tentang perbaikan desain kemasan dan pemasaran serta pelatihan dan pendampingan proses digitalisasi pemasaran/digital marketing melalui marketplace/sosial media. Melalui kegiatan ini, pelaku usaha diharapkan mampu mengelola usahanya menjadi lebih baik dan dapat memperluas pangsa pasar sehingga dapat mendukung perkembangan dan kemajuan usaha yang pada akhirnya dapat meningkatkan pendapatan bagi pelaku usaha UMKM keripik ciping.
\end{abstract}

Kata Kunci: Kemasan; Komersialisasi; Pemasaran; Digital Marketing.

\section{PENDAHULUAN}

Kemajuan akan perkembangan teknologi yang terjadi saat ini dimasyarakat adalah suatu proses yang tidak dapat kita dihindari dalam kehidupan saat ini, karena kemajuan teknologi yang terjadi berjalan sesuai dengan kemajuan ilmu pengetahuan. Setiap inovasi diciptakan untuk memberikan nilai manfaat yang positif dan memberikan banyak kemudahan bagi para pengguna, serta sebagai cara baru atau sebuah aplikasi berbasis teknologi dalam melakukan aktifitas didalam kehidupan manusia. 
Manfaat terknologi berbasis internet semakin sangat terasa bagi para pengguna yang tidak bisa lepas dari dunia internet, seperti misalnya para pengguna yang memanfaatkan aplikasi internet ini sebagai sarana dan prasarana kegiatan di media sosial misalnya pemberi informasi perjalanan, marketplaces, blogger dan juga toko online sangat berpengaruh dan tergantung pada internet khsusunya pada masa pademi covid-19. Berdasarkan total populasi Indonesia yang berjumlah 274,9 juta jiwa, maka itu artinya $73,7 \%$ penduduk Indonesia telah merasakan akses dunia maya.

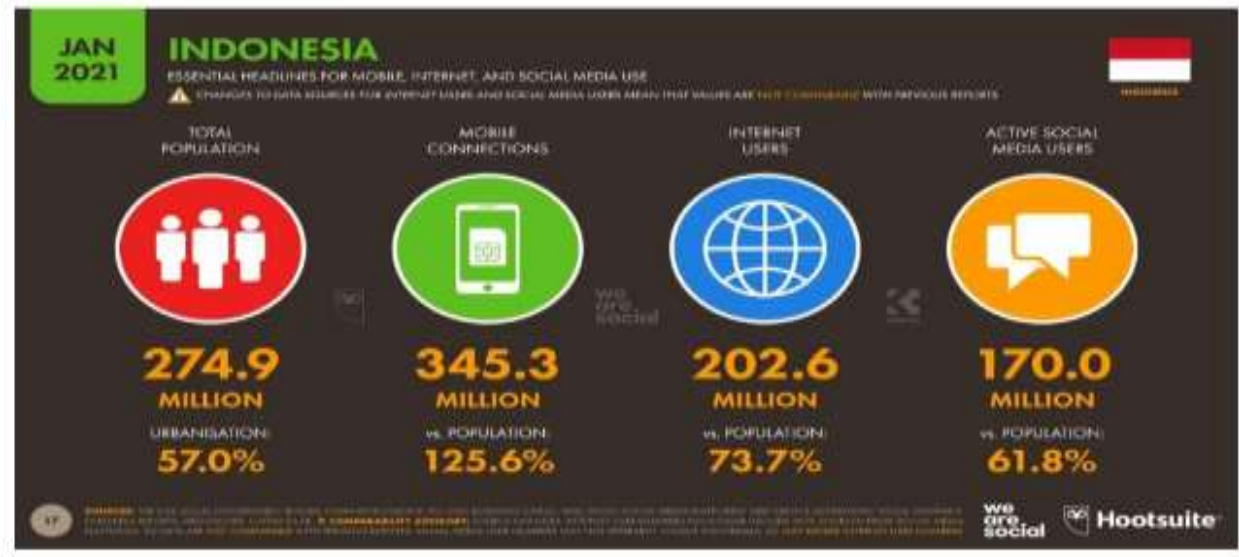

Gambar 1. Aktivitas Belanja Online

(https://www.iimers.com/data-perkembangan-digital-di-indonesia-tahun-2021/)

Dalam hal ini informasi melalui media sosial merupakan suatu sarana digital marketing yang paling mudah untuk dimanfaatkan dan dijalankan. Sebelum sebuah usaha memiliki akun dimedia sosial, tidak jarang kita dapat melakukan transaksi pembelian barang secara offline dimana pembeli dating langsung ke toko, kehadiran dunia digital ini dapat membantu dan merubah cara bertransaksi masyarakat untuk menggunakan aplikasi digital marketing melalui sosial media. Hal ini dapat menjadi stimulan perkembangan kewirausahawanan dan keberlangsungan UMKM. Selain biaya yang murah dan tidak perlunya keahlian khusus dalam memulai kegiatan untuk menjaring calon konsumen.(Febriyantoro \& Arisandi, 2018)

Salah satu kekuatan ekonomi yang selama ini menjadi penunjang ekonomi Negara Indonesia dan kekuatan ekonomi daerah adalah kehadiran pelaku usaha, mikro, kecil dan menengah (UMKM). Pada saat ekonomi dunia dan perekonomian Indonesia mengalami resesi, justru pelaku UMKM tidak sedikitpun tidak terkena dampak negatif resesi ekonomi tersebut, bahkan sebagian besar pelaku UMKM tetap dapat mengembangkan usahanya dalam menunjang perekonomian negara. Pelaku UMKM dapat mempertahankan dan meningkatkan kontribusi pertumbuhan ekonomi daerah serta peningkatan penerimaan pada sektor pajak negara, selain 
ditunjang oleh industri skala besar, juga ditunjang secara signifikan oleh kelompok-kelompok industri skala kecil

Daintaranya adalah UMKM produk keripik ciping yang berasal dari Desa Sukawana Curug Serang, pademi covid-19 merubah angka penjualan dimana pemasaran dari keripik ciping ini menurun drastis dari tahun-tahun sebelum masa pademi covid-19. Hal ini disebabkan penjualan yang dilakukan masih dengan cara menjual ke pasar-pasar tradional, menitipkan di warung dan hanya berdasarkan pesanan. Kondisi inilah yang membuat para pelaku UMKM Keripik Ciping membutuhkan strategi promosi yang tepat untuk menyikapi keadaan yang semakin memburuk agar bertahan dalam situasi yang tersulit dan tetap berupaya untuk "bagaimana caranya agar produk yang sudah diproduksi bisa terjual" pada masyarakat serta dapat meminimalisir kerugian yang dari sisi beban produksi. Tingkat pengetahuan masyarakat Desa yang masih kurang memadai akan peran digital marketing memungkinkan calon pembeli mendapatkan seluruh informasi mengenai produk dan bertransaksi melalui internet serta memungkinkan pelaku usaha kripik memantau dan menyediakan kebutuhan serta keinginan calon pembeli tanpa batasan waktu dan geografis. Tidak hanya itu juga digital marketing juga diperlukan untuk memperluas promosi produk yang dijual oleh pelaku UMKM, sehingga dapat meningkatkan pendapatan dan mengundang lebih banyak lagi calon konsumen untuk memesan produk yang hasilkan.

Berdasarkan hasil wawancara langsung kepada pelaku UMKM keripik ciping di Kelurahan Sukawana, salah satu kendala usaha keripik untuk berkembang adalah produk tersebut memiliki kelemahan dalam kemasan, memiliki merek yang tidak menarik, tidak memiliki jaringan pemasaran yang luas, masih minim pengetahuan dari pelaku UMKM tentang digital marketing dalam dunia usaha.

Produk keripik ciping yang ada di daerah ini juga, masih bersifat monoton atau tidak ada variasi dan inovasi yang dihasilkan serta kebanyakan dari mereka masih menggunakan sistem penjualan dan promosi secara fisik (dari mulut ke mulut), bisa dikatakan bahwa penggunaan teknologi pada sistem penjualan disini masih belum optimal. Para pelaku UKMK di Kelurahan Sukawana belum mengkolaborasikan media promosi konvensional dengan media digital.

Dengan manajemen usaha dan strategi pemasaran yang lebih baik, serta kemasan yang lebih menarik, pengetahuan dan penguasaan bagaimana memanfaatkan digital marketing oleh pelaku UMKM maka produk hasil usaha keripik ciping di Kelurahan Sukawana diharapkan akan dapat menangkap peluang pasar, mengembangkan usahanya dan mampu menjangkau pasar yang lebih luas lagi sehingga pada akhirnya dapat meningkatkan pendapatan dan 
melakukan ekpansi usaha. Salah satu Peluang pasar tersebut adalah sebagai oleh-oleh bagi wisatawan yang datang, dengan semakin berkembangnya pariwisata di Provinsi Banten.

\section{METODE}

Upaya untuk meningkatkan pemahaman tentang proses komersialisasi produk bagi usaha keripik ciping di Kelurahan Sukawana dilakukan melalui beberapa kegiatan, yaitu :

1. Penyuluhan mengenai perbaikan kemasan produk dan pemasaran.

Materi penyuluhan dalam kegiatan ini adalah berkaitan dengan desain kemasan dan digital marketing. Tujuannya adalah memberikan wawasan dan pengetahuan baru bagi pelaku UMKM keripik ciping di Kelurahan Sukawana. Penyuluhan/sosialisasi disampaikan dalam bentuk ceramah, tanya jawab dengan pemateri dan peserta.

2. Pelatihan dan pendampingan proses digitalisasi pemasaran melalui marketplace.

Materi pelatihan dan pendampingan adalah tentang bagaimana cara mendaftar pada akun di marketplace. Kegiatan ini bertujuan memberikan keterampilan tentang cara mengelola akunakun tersebut agar mudah ditelusuri oleh calon konsumen dalam mencari berbagai jenis usaha kripik ciping.

Perbaikan manajemen usaha, kemasan dan pemasaran produk, diharapkan dapat membantu pengusaha dalam komersialisasi produk yang dihasilkan. Hal ini terkait dengan kemampuan inovasi usaha, mengembangkan produk serta memasarkannya pada era digital atau sosial media saat ini dan pada mada pademi covid-19. Produk unggul yang menarik dan memiliki ciri khas khusus akan membantu proses komersialisasi menjadi lebih mudah, karena produk seperti ini akan sangat mudah diingat, apalagi jika ditambah dengan karakteristik yang menunjukkan bahwa produk merupakan ciri khas lokal yang dapat menjadi sumber pendapatan masyarakat. Evaluasi yang akan dilakukan terkait dengan pelaksanaan kegiatan ini adalah :

1. Aspek pengetahuan : Bertambahnya pengetahuan dan kemampuan pengusaha keripik ciping dalam konsep penjualan produk.

2. Aspek pelaksanaan diukur dengan penerapan konsep manajemen usaha yang berbasis digital marketing guna meningkatkan pendapatan dan produktivitas para pelaku usaha keripik ciping dan dapat memberikan manfaat positif bagi seluruh masyarakat.

\section{HASIL DAN PEMBAHASAN}

E-Marketing atau digital marketing diartikan sebagai penggunaan teknologi digital untuk mencapai tujuan pemasaran serta upaya pengembangan atau penyesuaian konsep pemasaran itu sendiri, dapat berkomunikasi dalam cakupan global, dan mengubah cara perusahaan melakukan bisnis dengan pelanggan. (Ikhsana et al., 2019; Khairusy, 2021; 
Mardiani Endang \& Imanuel, 2013). Dapat disimpulkan bahwa Digital marketing merupakan pemasaran dengan menggunakan penerapan teknologi secara digital. Salah satu bentuk marketing digital dengan menggunakan media elektronik atau internet adalah internet marketing (e-marketing). E-Marketing merupakan suatu proses pemasaran yang menggunakan teknologi komunikasi elektronik, khususnya internet. Peran strategi digital marketing dapat menjadi hal yang penting dalam mengikuti perkembangan teknologi digital dan mengembangkan rencana untuk menarik konsumen dan mengarahkannya pada perpaduan antara komunikasi elektornik dan komunikasi tradisional.

Menurut Chaffey (2006) retensi tersebut dapat dicapai dengan meningkatkan pengetahuan tentang konsumen seperti profil, perilaku, nilai, dan tingkat loyalitas, kemudian menyatukan komunikasi yang ditargetkan dan pelayanan online sesuai kebutuhan masingmasing individu. Digital marketing adalah kegiatan marketing termasuk branding yang menggunakan berbagai media berbasis web seperti blog, website, e-mail, adwords, ataupun jejaring sosial.

Menurut UUD 1945 tentang Politik Ekonomi dalam rangka Demokrasi Ekonomi, Usaha Mikro, Kecil dan Menengah perlu diberdayakan sebagai bagian integral ekonomi rakyat yang mempunyai kedudukan, peran dan potensi strategis untuk mewujudkan struktur perekonomian nasional yang makin seimbang, berkembang dan berkeadilan melalui (Rakyat \& Indonesia, 1998). Selanjutnya dibuatklah pengertian UMKM melalui Undang-Undang No.20 Pasal 1 Tahun 2008 tentang Usaha Mikro, Kecil dan Menengah maka pengertian UMKM adalah sebagai berikut : 1) Usaha Mikro adalah usaha produktif milik orang perorangan dan/atau badan usaha perorangan yang memenuhi kriteria Usaha Mikro sebagaimana diatur dalam Undang-Undang ini. 2) Usaha Kecil adalah usaha ekonomi produktif yang berdiri sendiri, yang dilakukan oleh orang perorangan atau badan usaha yang bukan merupakan anak perusahaan atau bukan cabang perusahaan yang dimiliki, dikuasai atau menjadi bagian baik langsung maupun tidak langsung dari Usaha Menengah atau Usaha Besar yang memenuhi kriteria Usaha Kecil sebagaimana dimaksud dalam Undang-Undang ini. 3) Usaha Menengah adalah usaha ekonomi produktif yang berdiri sendiri, yang dilakukan oleh orang perorangan atau badan usaha yang bukan merupakan anak perusahaan atau cabang perusahaan yang dimiliki, dikuasai atau menjadi bagian baik langsung maupun tidak langsung dengan Usaha Kecil atau Usaha Besar dengan jumlah kekayaan bersih atau hasil penjualan tahunan sebagaimana diatur dalam Undang-Undang ini. 4) Usaha Besar adalah usaha ekonomi produktif yang dilakukan oleh badan usaha dengan jumlah kekayaan bersih atau hasil penjualan tahunan lebih besar dari Usaha Menengah, yang meliputi usaha nasional milik Negara atau swasta, usaha patungan dan usaha asing yang melakukan kegiatan ekonomi di Indonesia. 5) Dunia Usaha adalah Usaha 
Mikro, Usaha Kecil, Usaha Menengah, dan Usaha Besar yang melakukan kegiatan ekonomi diIndonesia dan berdomisili di Indonesia ((Indonesia, 2008; Suci, 2017).

Kegiatan pelatihan diadakan pada tanggal 11 Agustus 2021 dan diikuti oleh Ibu-ibu pelaku UMKM keripik ciping yang ada di Kelurahan Sukawana. Kegiatan pengabdian ini bertujuan agar mitra mampu memahami konsep penjualan produk yang meliputi desain kemasan dan sistem pemasaran dengan memanfaatkan teknologi digital marketing, sehingga produk yang dihasilkan memiliki nilai jual yang tinggi dan market pasar yang lebih luas.

Tahapan kegiatan yang diberikan mulai dari pemberian materi/sosialisasi tentang literasi digital marketing dan pendampingan pembuatan akun marketplace seperti: Shopee, Facebook, Lazada dll. Serta perbaikan desain kemasan dan sistem pemasaran.

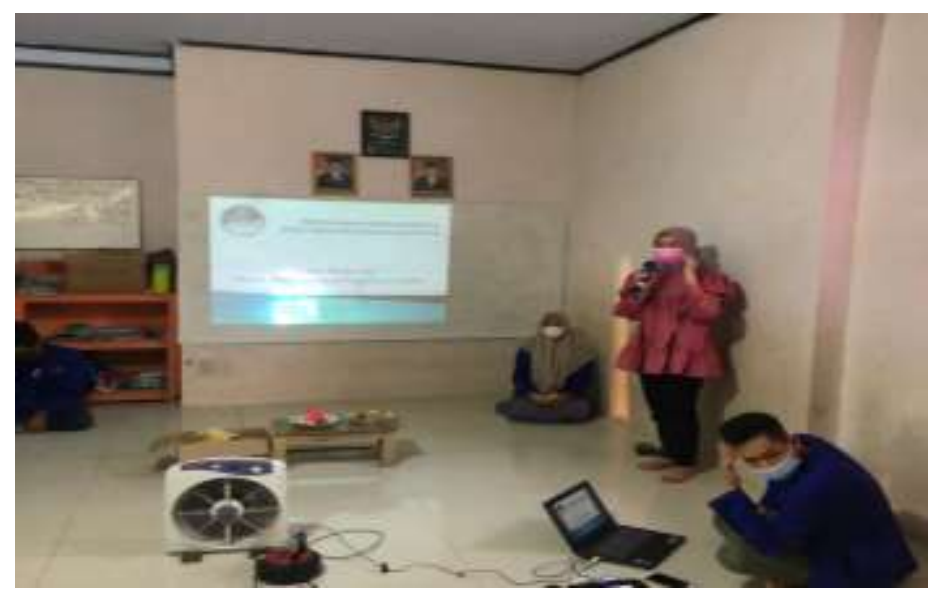

\section{Gambar 2. Sosialisasi Komersialisasi Produk \& Digital Marketing}

Kemasan produk keripik ciping identik dengan kemasan sederhana sehingga perlu dilakukan sedikit perubahan agar menjadi lebih menarik. Produk keripik ciping tidak dapat hanya mengandalkan kualitas produk saja, tetapi kualitas kemasan juga perlu diperhatikan untuk mampu menarik perhatian konsumen sehingga produk yang ditawarkan akan lebih laku terjual dari sebelumnya, dan pada akhirnya dapat meningkatkan penjualan.

Perbaikan desain kemasan perlu dilakukan untuk membangun citra produk keripik ciping agar mampu tumbuh sejajar dengan produk industri lainnya yang sudah besar dan sudah berada lama dipasaran. Selain itu, produk dengan desain kemasan yang menarik memiliki nilai tawar yang tinggi dan dapat dengan mudah memasuki pasar modern.

Kemasan adalah bagian pertama produk yang dihadapi pembeli dan mampu menarik atau menyingkirkan pembeli. Berdasarkan pengertian tersebut pemateri memberikan tips dalam mendesain kemasan agar terlihat lebih menarik: (1) ciptakan nama merk yang unik dan berbeda, sehingga menjadi ciri khas dari produk tersebut dan selalu diingat oleh konsumen; (2) buat 
tagline produk yang dapat langsung dikenali oleh konsumen, singkat dan mudah diingat, serta memperhatikan segmen pasar sehingga dapat menjadi top of mind di benak konsumen; (3) tentukan warna dominan yang akan digunakan, pelajari psikologi warna berkaitan dengan selera konsumen, ada baiknya dilakukan survei terlebih dahulu; (4) buatlah konsep kemasan yang tidak biasa, dengan memperhatikan aspek kemudahan bagi konsumen dalam membawa dan membuka kemasan; (5) labelkan tanggal kadaluarsa, izin usaha dari Dinas Perindustrian dan Dinas Kesehatan, serta cantumkan label halal produk dari MUI; (6) cantumkan daftar bahan yang digunakan dalam produk tersebut, dan menguraikan tentang bagaimana cara mengkonsumsinya; (7) sertakan nomor untuk konsumen memberikan kritik dan saran demi perbaikan produk.

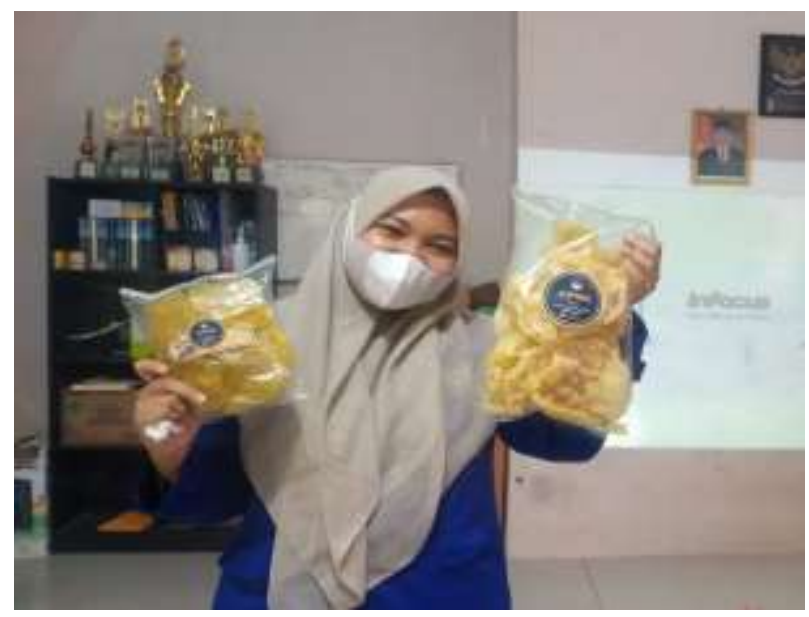

\section{Gambar 3. Kemasan Produk Keripik Ciping}

Selama proses pendampingan dilaksanakan terdapat perubahan desain kemasan pada keripik ciping, yaitu menggunakan standing pouch atau plastik klip berdiri transparan. Namun nilai/harga produk menjadi bertambah secara ekonomi karena kemasan yang berubah dan desainnya yang lebih menarik dari sebelumnya. Dengan kata lain, produk dengan kemasan yang berbeda/lebih terlihat menarik akan menciptakan harga dan segmen pasar yang berbeda pula.

Berdasarkan hal tersebut, dapat disimpulkan bahwa pelaku usaha harus terus melakukan pengembangan dalam manajemen usaha, baik itu inovasi produk, kemasan maupun sistem pemasaran.Kegiatan pengabdian ini mendapatkan respon yang sangat baik dari pelaku UMKM, hal ini terlihat dari antusias peserta dalam diskusi dua arah dengan para pemateri yang berjalan lancar dan hangat. Peserta mengatakan kegiatan ini sangat membantu mereka dalam membuat kemasan yang bagus dan komersil, menambah pengetahuan tentang media platform google bisnisku, memilih strategi promosi yang efektif dan proses memasarkan produk yang lebih mudah sehingga meningkatkan ketertarikan calon pembeli dan para pelaku UMKM Keripik 
Gampong Karang Anyar dapat memiliki pangsa pasar yang lebih luas dari sebelumnya sehingga dapat meningkatkan pendapatan dan ekpansi Usaha.

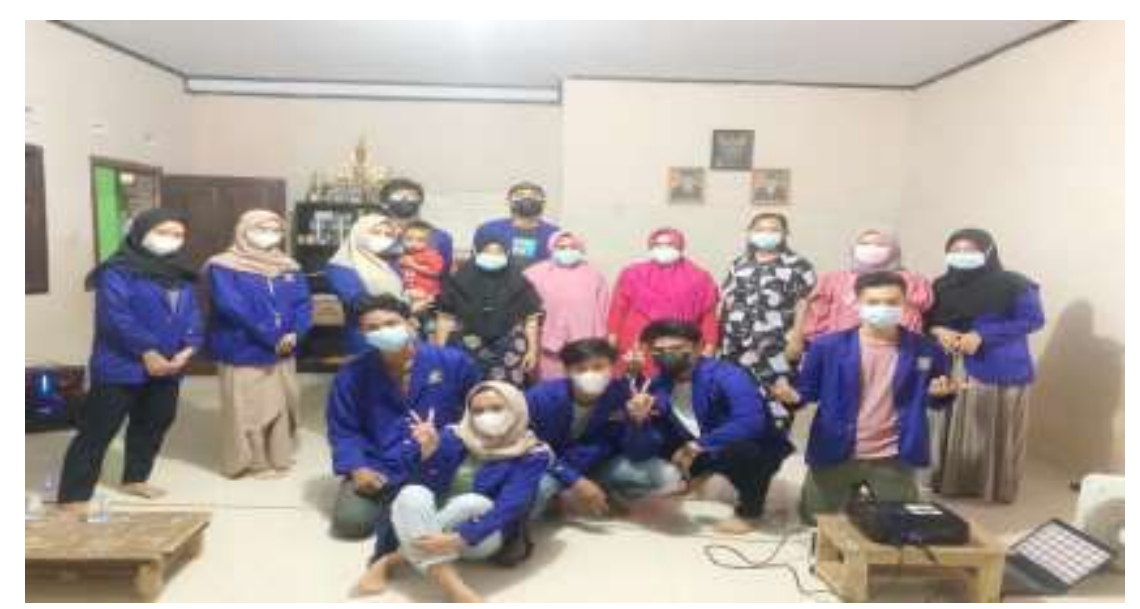

Gambar 4. Foto Bersana Peserta Penyuluhan dan Pemateri

\section{KESIMPULAN}

Pemberian pelatihan dan sosialisasi tentang literasi digital marketing dan manajemen usaha khususnya yang berkaitan dengan desain produk dan pemasaran digital/digital marketing bagi pelaku UMKM keripik ciping di Kelurahan Sukawana memiliki dampak yang positif bagi pelaku UMKM agar dapat mengelola usahanya menjadi lebih baik dan memperluas market pasar sehingga dapat mendukung perkembangan dan kemajuan usaha yang pada akhirnya dapat meningkatkan pendapatan masyarakat.

Meskipun hasil pelatihan sudah menunjukkan peningkatan wawasan dan pengetahuan pada para pengusaha keripik ciping mengenai penjualan produk khususnya yang berkaitan dengan desain kemasan dan pemasaran secara online. Selain itu, perlu adanya dukungan dari pemerintah Kementerian Koperasi dan Usaha Kecil Menengah (UKM) bekerja sama dengan Kementerian Riset Teknologi dan Pendidikan Teknologi dengan cara mengadakan/memberikan pelatihan untuk menambah wawasan dan informasi serta membuat wadah/komunitas bagi para pelaku UMKM untuk dapat saling berinteraksi dan berbagi informasi terkait tips dan trik untuk digital marketing.

\section{DAFTAR PUSTAKA}

Chaffey, D. (2006). Additional student support at www.pearsoned.co.uk/chaffey. In Practice.

Febriyantoro, M. T., \& Arisandi, D. (2018). Pemanfaatan Digital Marketing Bagi Usaha Mikro, Kecil Dan Menengah Pada Era Masyarakat Ekonomi Asean. JMD: Jurnal Riset 
Manajemen \& Bisnis Dewantara, 1(2), 61-76. https://doi.org/10.26533/jmd.v1i2.175

Ikhsana, P. D., Prisanto, G. F., \& Anggraini, R. (2019). Penerapan Strategi E-Marketing Communication Dan Ekuitas Merek Siaranku.Com Terhadap Loyalitas Viewers. Inter Komunika : Jurnal Komunikasi, 4(1), 58. https://doi.org/10.33376/ik.v4i1.217

Indonesia, P. R. (2008). Undang-Undang Republik Indonesia Nomor 20 Tahun 2008 (Issue 1).

Khairusy, M. A. (2021). Pengemasan Produk Sebagai Upaya Pengembangan Pemasaran Industri Kerupuk Emping (Kruping) Studi Observasi Kp. Cilowong. Jurnal Manajemen Dan Bisnis, 112-123. http://ejournal.lppm-unbaja.ac.id/index.php/jmb/article/view/1209

Mardiani Endang, L. Q., \& Imanuel, O. J. (2013). Analisis Keputusan Pembelian Konsumen Melalui Media (Vol. 4, Issue November).

Rakyat, M. P., \& Indonesia, R. (1998). Majelis permusyawaratan rakyat republik indonesia. 91-98.

Suci, Y. R. (2017). Development of MSME (Micro, Small and Medium Enterprises) in Indonesia. Jurnal Ilmiah Cano Ekonomos, 6(1), 51-58. 